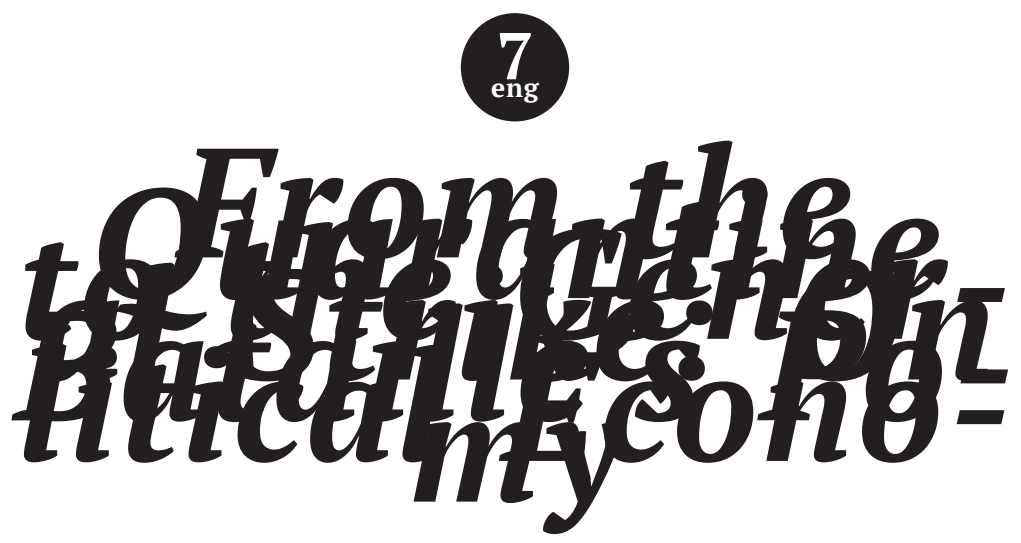

\author{
Oxana Timofeeva \\ Professor, Leading researcher \\ European University at St Petersburg, Tyumen State University, \\ 6/1A Gagarinskaya Street, 191187 St Petersburg \\ E-mail: otimofeeva@eu.spb.ru

\section{From the Quarantine to the General Strike: On Bataille's Political Economy ${ }^{1}$}

\begin{abstract}
:
The essay explores Bataille's general economy as the theory of nonproductive expenditure and its implications for a new politics of nature. It suggests that this theory, elaborated by Bataille in the 1940s, can be valid today and applicable in the analysis of the most urgent problems of contemporary humanity such as the COVID-19 pandemic or climate change. The reading of general economy that is presented in this essay evokes the Bataillean

${ }^{1}$ The results were obtained in the framework of the grant of the Russian Science Foundation, project No 20-68-46044 "Imaginary Anthropocene: environmental knowledge production and transfers in Siberia in the XX-XXI centuries.”
\end{abstract}


notion of violence, which allows the political aspects of the human/nonhuman divide to be exposed. The essay begins with the metaphor of the sun as the source of both destructive and productive energy, continues with the reflections of the two kinds of violence, as well as two kinds of economies in Bataille, defines

a passage between general economy and a possible general politics, and finally proposes to critically reconsider Bataille's opposition between labor and nature in order to overcome it.

\section{Keywords:}

Georges Bataille, general economy, nonproductive expenditure, COVID-19, climate change, general strike

This essay is a starting point of a bigger investigation that aims to connect two massive theoretical models, which, at first glance, seem absolutely incompatible - Karl Marx's communism grounded on the concept of universal labor as the essence of the human, and Georges Bataille's general economy oriented toward nonproductive expenditure as an experience of the nonhuman. Whereas Marx envisages the roots of communism in the essential freedom of human productive activities, which must historically rid itself from the bonds of capitalist alienation, Bataille's route to liberation passes through the debris of luxurious destruction learned from the life of nature. However, both Marx and Bataille present fundamental critiques of capitalist political economy, elaborate on epistemological horizons of inventing new forms of social organization, free from inequalities and abuse, and provide strong theoretical tools for thinking nature politically. I have repeatedly addressed Marx, as well as Bataille, in my previous work; they are among the few authors to whom I often find it appropriate to refer, but until now they occupied, so to speak, two separate toolboxes on my philosophical shelf. When I started to outline my first ideas about the politics of nature, I realized that I simply could not decide which of the two boxes to pick up, and must find a way to take both. For this, some preliminary work must be done, which is what this essay is designed for. It only addresses Bataille, not Marx. But I reread Bataille in pursuit of furthering a new mode of conceptualizing Marxian political economy in relation to ecology.

Let me briefly contextualize this intention. On the one hand, my reflections on the politics of nature engage with the problem of labor that must be reconsidered with regards to the nonhuman, or, rather, the not-necessarily-human, world. To put it briefly, I suggest expanding the domain of universal production - which, for Marx, 
defines the essence of the human - toward nonhuman things. Everybody and everything - bees, horses, humans, robots, stars, and trees - can be qualified as universal producers, as their work necessarily contributes to the ecological whole. You withdraw one working species - say, bees - and the entire chain of the production of life falls under the threat of collapse. In this perspective, the exploitation not only of workers, but of natural resources or other things, including artificial intelligence, becomes the source of a principal antagonism that cannot be resolved within the system of capitalist extraction.

On the other hand, Bataille's general economy introduces the domain of the nonhuman that remains alien to all restrictive economic activities of human beings on Earth. The more that will be produced and accumulated by humans, the more will be destroyed on the planetary level, as there are natural phenomena that humanity can neither appropriate nor even properly control - such as epidemic outbursts, global warming with its multiple effects, tsunamis, or volcanic eruptions. These planetary activities are opposed to work: according to Bataille, they rather express the idle wastefulness of nature that time and again seem to obstruct the processes of capitalist accumulation and economic growth. Thus, a single virus kills thousands of people, but also crashes the markets worldwide: factories are closed, workers stay home. What humanity conceives as a huge problem, indifferent nature celebrates as abundance and splendor.

These two models generate two ideas of nature clearly opposed to each other. The Marxist approach to environmental issues presents nature-the-oppressed, the exploited, nature-the-worker. Colonized, sucked up by capitalist extractive machines, it rebels or dies. In the Bataillian perspective, in contrast, humanity is confronted by nature-the-sovereign, powerful and essentially free: spreading death as the festive appearance of general life, it will triumph over all human efforts to transform it into profitable commodity-objects: the oil will spill and contaminate the land, the fires will burn the woods, the locusts will destroy the harvest, a pandemic will break the production process. The two models can be grasped as a dialectical contradiction in a single image of the sun: it is both productive and destructive; it provides light and warmth that are enough for all earthy things to exist, it can be endlessly used for the needs of humanity, but it can also blind you or burn you down.

This essay explores only one side of this contradiction, namely Bataille's general economy as the theory of nonproductive expenditure and its implications for a new politics of nature. I argue that this theory, elaborated by Bataille in the 1940s, can be valid today and 
applicable in the analysis of the most urgent problems of contemporary humanity such as the COVID-19 pandemic or climate change. But I certainly do not consider it as a ready-made, accomplished theoretical model that can be applied to this or that empirical data. For me, general economy is an open book, still in the making, and our new historical experiences not only seem to confirm its appropriateness, but also provide initially missing elements that would allow this work to continue and be developed in new directions. In particular, I propose that Bataille's general economy can be reconciled with its Marxist counterpart, and the politics of nature is what empowers the prospects of such an encounter.

My reading of general economy evokes the Bataillean notion of violence, which allows for the political aspects of the human/nonhuman divide to be exposed. I emphasize that Bataille develops an original apology of violence that is not human - an indifferent, non-violent violence of nature, which, in his theory, corresponds to the general economy and is incompatible with human-restricted activities. Today's tendencies to interpret the disastrous appearances of climate change or pandemics as nature's revenge over the violence of the Anthropocene, indeed, pay justice to it, but at the same time remain all-too-human, missing this moment of nature's irreducibility and autonomy. Bataille reminds us about this distinction, but, in my perspective, his intention to overcome it is obstructed by missing one very important link, that is, labor, which Bataille considers in a kind of unilateral way as an element of specifically human, restricted, profane economies. I think that what connects labor and nature is the notion of energy in its non-metaphysical, materialist aspect, which is now developed by the energy humanities and Marxist energy critique "between two fields that condition the present - environmental catastrophe and capitalist crisis" (Bellamy and Diamanti 2018: ix). Without analyzing this connection here, I only indicate the way of thinking nature through this dialectic, which starts from the metaphor of the sun as the source of both destructive and productive energy and reflects upon the ways of dealing with it.

\section{The God of Violence}

Bataille was an untimely thinker - definitely not an academic philosopher, he developed conceptions that were too radical to be included in the official theoretical canon. In an age of rising fascist mobilization, he was trying to reappropriate notions of the sacred, violence, and sovereignty, and make them work against fascism. 
Militantly unsystematic, he integrated ideas of Nietzsche, Hegel, Sade, Freud, and Marcel Mauss into a complex theoretical machine of transgression, pushing thought beyond prohibitions. Bataille does not respect disciplinary borders: in his writings, anthropology, political economy, philosophical ontology, psychoanalysis, literary and art criticism intertwine in such a way that we cannot register the moment when, say, eroticism becomes both cosmology and the analysis of power systems. Today, a new region of Bataille's thought begins to attract attention - his base materialism that goes against all the materialist mainstream and considers heterogeneous matter as analogous to the Freudian unconscious with its principal ambivalence, and his original philosophy of nature that throws fresh light on environmental issues. I will focus on the image of the sun, that connects these early base materialist conceptions with fundamental ecological insights.

In his very short contribution to Documents magazine, "Rotten Sun" (1930), dedicated to Picasso's painting, Bataille tackles the ambiguity of the sun. There is the "elevated" sun of the mind, and there is the rotten sun of madness and unheard-of violence. The first one, "confused with the notion of the noon," exists as an abstract object "from the human point of view," whereas the second points to ancient bloody cults and rituals of sacrifice. Bataille recalls the myth of Icarus that "clearly splits the sun in two - the one that was shining at the moment of Icarus's elevation, and the one that melted the wax, causing failure and a screaming fall when Icarus got too close" (Bataille 1985: 58). His essay “The Solar Anus" written in 1927 and published in 1931, enhances the obscenity and violent aspects of the sun that is listed, together with coitus, cadavers, or obscurity, among the things that human eyes cannot tolerate. In "The Solar Anus," Bataille's cosmology is presented in a very condensed fashion: it draws a picture of a dynamic and decentered universe where each thing "is the parody of another, or is the same thing in a deceptive form" (Ibid: 5). Each thing can be equally proclaimed as the principle of all things, and is dragged into the two primary motions that transform into each other - "rotation and sexual movement, whose combination is expressed by the locomotive's wheels and pistons" (Ibid: 6). As Stuart Kendall explains: “'The Solar Anus' articulates a myth of general economy, a vision of the circulation of all energies not only around the globe but within the cosmos" (2007: 55). This circulation is expressed through a seemingly impossible, parodic unity of opposites: "the opposite of pure solar energy is terrestrial filth, excrement; the myth of the solar anus proposes the unity of these forces" (Ibid). Parody is the principle of Bataille's dialectics. 
Unlike Hegel's unfolding of spirit, this dialectics is a base materialist one; it inscribes solar contradiction at the junction of eroticism, ontology, politics, and epistemology. Bared of its metaphysical mask of the supreme Good, parodied by all kinds of erections (plants, trees, animal bodies) and involved into a constant movement of the "polymorphous and organic coitus" (Bataille 1985: 7) with the earth, Bataille's sun directs toward it its "luminous violence," whose perfect image is a volcano (Ibid: 9).

I have only quoted two of Bataille's essays where the sun is associated with violence, but in fact this association features as a constant theme of his writings, and the sense of it is deeper than it might appear on the face of it. Conceptualizing the link between the sun and violence with regard to questions of economy and the distribution of energy demands an attempt to clarify the notion of violence in Bataille, which is very much different from commonplace ideas more or less familiar to all of us from the contexts of contemporary life and theory. Today, the word "violence," applied to various kinds of destructive actions and affections, becomes inflated. Sexual, gender, domestic, ethnic, state or police violence, as well as emotional abuse, are broadly discussed as purely negative social phenomena that must be diagnosed, identified, and minimized or eliminated. There is a moral ban that does not allow us to accept anything that could be interpreted as violence or something that generates it.

However, if we look back at twentieth-century theory, we discern a minor, yet interesting tendency of an apology for violence that exists within the leftist tradition. There are grounds for believing that Bataille belongs to this tendency - together with thinkers like Georges Sorel, Walter Benjamin, and Frantz Fanon. I put these four names together, because, in spite of serious differences, there is a structural homology between their conceptions of violence that can be described through the dialectical movement of the double negation. Namely, in these conceptions, there are always two types of violence - the one that we reject, and the one that we appreciate, validate, provide, or fantasize about. Thus, Sorel (2004) opposes a supreme proletarian violence of the general strike to the brutal violence of the capitalist state system; Benjamin (1996: 236-52) introduces the divine, or revolutionary violence contesting the violence of the law; Fanon (1963: 35-106) formulates the idea of the resistance of colonized people that becomes even more violent and brutal than the colonial regime against which it raises. In all these cases, the second, true violence-upright, just, rebellious, emancipatory or redemptive-destroys a preceding, stupid violence of a certain established system of the relationship of power. 
Bataille, too, differentiates between two kinds of violence. As emphasized by Benjamin Noys: "Bataille explores the violence of difference in a reading of violence as a general economy. This requires careful and critical reading because it becomes easy to assimilate Bataille to a culture of violence, and all too often 'celebrations' of Bataille do just that. However, in breaking the (violently imposed) taboos on violence Bataille is not aiming to increase violence but to examine how these strict taboos generate their own violence" (2000: 134). I fully agree with this claim, and suggest tracing the connection between violence and general economy from Bataille's late essay "Pure Happiness" (2001), where violence as a sovereign unlimitedness is opposed to the limits violently imposed by reason. What reason does is a constant operation of limitation: thought creates a sphere of things that are thinkable, that is, reducible to certain categories of reason. In this operation, something is necessarily excluded, and it is precisely this something that creates the domain of violence, or, as Bataille otherwise calls it, the sacred.

Yes, for Bataille, violence and the sacred are often synonymous. The sacred is that which has been excluded by reason, first of all, as animality, as an unthinkable nature. It is, in Kathryn Yusoff's words, "...excluded from the ledger and returns as a destructive force because it has not been properly accounted for" (2015: 393). Such an exclusion can be compared to the process of repression, in a Freudian sense (Freud 1965: 141-58), followed by the return of the repressed, or to the suppression of aggression that, without finding a way out, transforms into mental illness, as in case of the oppressed people in colonies (Fanon 1963: 249-310). According to Bataille, the excluded is produced by reason that, positing the limits, functions as a kind of policeman: what it excludes from its domain becomes the object of its fundamental interrogation, for which violence "offers itself as the only answer" (Bataille 2001: 228). Bataille further suggests that such an answer "can only come from the outside, from that which thought had to exclude in order to exist," and identifies it with God himself: "Is not God an expression of violence offered as a solution?” (Ibid).

Bataille's equation of God with violence resonates highly with the concept of divine violence, which, according to Benjamin's materialist political theology, breaks the vicious circle of the mythic, that is, law-making and law-preserving violence (Khatib 2011: 5). Benjamin invites us to think of violence not in terms of needs and ends, but in terms of a pure manifestation. Mythic violence manifests the power of the strongest, the law, the Father, whereas divine violence manifests justice. Imagine a situation, as simple as it is 
paradigmatic, of people being brutally beaten by the police. The law is on the side of the police officer, whereas nothing seems to be on the side of the people that are beaten. One says "Only God could help them!" meaning that nothing could really help these people: the law itself becomes an instance of an ultimate injustice. There is, however, still another kind of violence at people's disposal, one that is outside the law. This violence is divine not because it comes from God, but because it is in place of God. It is "sovereign" (Benjamin 1996: 252) in a sense that "there is no big Other guaranteeing its divine nature" (Žižek 2008: 200), no police officer, and no God other than this violence itself, but also in a sense that, in contrast to the "administrative" mythic violence, it serves no goal; it just strikes. Divine violence is "the sign and seal but never the means of sacred dispatch" (Benjamin 1996: 252).

Likewise, "full violence," according to Bataille, "can be the means to no end. It would be subordinate to no goal" (2001: 229). As he explains in the notes to "Pure Happiness": "Violence reduced to a means is an end in the service of a means - it is a god become a servant" (Ibid: 291-92). However, there is a significant difference between these conceptions. While in Benjamin divinity appears as a manifestation, or a "sign and seal" of justice, Bataille's god of violence is alien to any moral categories of this kind. It cannot be just or unjust, but is absolutely indifferent and stands beyond good and evil. It is not a God of theology, but rather "the animal god" whose "incomparable purity" and "violence above laws" Bataille invites us to discover (Ibid: 228). Further he introduces the following distinction:

I imagine two kinds of Violence.

The victim of the first kind is led astray.

It is the Violence of a rapid train at the moment of the death of the despairing person who willfully threw himself on the tracks.

The second kind is that of the serpent or the spider, that of an element which is irreconcilable to the order wherein the possibility of being is given, which turns you to stone. It does not confound but slips; it dispossesses, it paralyzes, it fascinates before you might oppose anything to it.

This kind of Violence, the second kind, is in itself imaginary. It is nevertheless the faithful image of a violence, this measureless violence without form, without method - that at any moment I can equate with God. (Bataille 2001: 232)

In the image of the train that will run us down, a reader can recognize the idea of the limited and limiting violence of the police 
of reason, structurally similar to Benjaminian mythic violence, or the state violence to which Sorel opposed a general strike, or the violence of the white colonizers described by Fanon. However, the second kind of violence according to Bataille introduces something completely new. The god of violence is not only animal; it is nonhuman in a broader sense. Violence as an answer to the limitations of reason breaks the borders of the human; it is non-anthropomorphic and non-anthropocentric. I cannot identify with a serpent, a spider, or with a hurricane in the way I could identify with the struggles of people in colonies or with workers on strike. It belongs to the world of immediacy and immanence, where, according to Bataille, animals eat one another, but those who eat do not really differentiate themselves from those whom they eat, do not conceive them as separate objects. Nonhuman violence is without a subject. No one really commits it, no one is to blame. I cannot blame a wolf for eating a calf. Predation and other forms of violence inherent in the animal world are compared to the movement of the sea waves swallowing each other: "every animal is in the world like water in water," Bataille writes in the Theory of Religion (1989: 19).

\section{General Economy, Pandemic, and Climate Change}

To be sure, the two kinds of violence in Bataille correspond to the two kinds of economy analyzed in the first volume of his fundamental book The Accursed Share (1949). The volume begins with the admission that, for some years, Bataille was embarrassed to have to say that he was working on "a book of political economy" (1991: 9). It was a very ambitious project, indeed, mainly because the sort of political economy proposed by Bataille seems to have nothing to do with traditional works in the field. It begins from the critique of political economy as we know it. This is quite a Marxian gesture: remember that Marx criticizes bourgeois economists for considering a worker not as a human being, but as a working horse, and labor not as a human essence, but as a commodity that one can sell or buy (Marx 1959), and then applies a class perspective to the analysis of the system of capitalist production based on the exploitation of human and natural resources. Bataille's criticism is different: in his view, the main problem of economists is that they discuss production rather than consumption and only focus on human affairs without taking into consideration "the general problem of nature" (Bataille 1991: 13). The vast majority of economic science takes its objects as isolated phenomena - for instance, the car industry or agricultural 
sector - but the principal question raised is: "Shouldn't productive activity as a whole be considered in terms of the modifications it receives from its surroundings or brings about in its surroundings? In other words, isn't there a need to study the system of human production and consumption within a much larger framework?” (Ibid: 20).

It is important to note that Bataille was one of the first European thinkers who began to articulate a connection between economy and ecology, and to reflect on environmental processes, which human beings cannot really estimate, and of which they are nevertheless a part. By "a much larger framework" Bataille means "the general problems that are linked to the movement of energy on the globe" (Ibid: 20). This is the theme of general economy-an untimely, extraordinary precursor of the new cutting-edge domain of contemporary research today known as energy humanities. As Imre Szeman and Dominic Boyer explain in their introduction to a reader on this field of knowledge, the energy humanities address global warming and other major ecological issues beyond the framework of positive natural and technological sciences: "Environmental scientists have played a crucial role in identifying the causes and consequences of global warming [...]. However, the next steps in addressing environmental crisis will have to come from the humanities and social sciences - from those disciplines that have long attended to the intricacies of social processes, the nature and capacity of political change, and the circulation and organization of symbolic meaning through culture" (Szeman and Boyer 2017: 3). The energy humanities aim to "grasp the full intricacies of our imbrication with energy systems," and "make out other ways of being, behaving, and belonging in relation to both old and new forms of energy" (Ibid).

In his time, Bataille was inspired by the idea of founding such a syncretic science that would consider the physical, geological, sexual, philosophical, and political in their mutual intersection, which, as proclaimed throughout "The Solar Anus," is ultimately parodic. He did not have enough discipline to complete this science into a proper system (he hated completed systems; maybe that is why his promises given in the preface and theoretical introduction to The Accursed Share were not really carried out...), but he gave it a good name - general economy. Energy for general economy is not only what matters, but what matters the most. Its currents define all economic life. Today we know it very well. We are, however, used to thinking of energy as a limited resource for all productive activities. For Bataille, this was not the case. He saw the problem not in the lack, but in the excess of energy. We, living organisms, receive more energy than we really need and can accommodate. In this sense, we 
are not poor, but rich, as is everything and everybody on Earth. It is because of this excessive energy that all animals and plants can grow and reproduce, but even growth and reproduction cannot exhaust what we receive for no cost. The overall growth is limited by "the size of the terrestrial space" (Bataille 1991: 29), within which animals and plants develop, invade the lands, crowd and replace each other. Life itself is an extravagant luxury with death as its culminating point. Living forms rotate in nature's macabre dance.

A superabundance of energy comes from the sun: "Solar energy is the source of life's exuberant development. The origin and essence of our wealth are given in the radiation of the sun, which dispenses energy - wealth - without any return. The sun gives without ever receiving" (Ibid: 28). Be like the sun! - this is basically a Bataillean motto for the possible future of the political economy adjusted to the planetary scale and balanced with the ecological whole. General, or solar economy is the economy of gift as opposed to one of exchange, it privileges consumption over production and expenditure over accumulation. How to imagine such an economy? Bataille provides an example of extreme poverty in India contrasted to excessive wealth in the US: "General economy suggests, therefore, as a correct operation, a transfer of American wealth to India without reciprocation" (Ibid: 40). This sounds like a simple solution, but at the same time absolutely impossible. Why? Because we are used to thinking about such matters in terms of restricted human economies. We consider social life as interactions of separate objects, individuals or groups, national states, and other units, with their specific needs, interests, or functions, whereas general economy only comprises the planetary whole and its equilibriums. In fact, it cannot be practiced by humans within the system of capitalist states, based on accumulation and ownership, where all things seem to be designed for being not distributed for free, but possessed and exchanged at a profit. As Amanda Boetzkes comments on the place of solar energy in Bataille's ecological thinking, his account of solarity implies that "a global infrastructure that drew from a freely available source is inimical to capitalism's restricted energy economy" (Boetzkes 2017: 317). In a similar vein, Imre Szeman (2020) explains that we can, indeed, imagine a global transition to "cleaner" solar energy that would replace more "dirty" fossil fuels, but such a solar-energy-based capitalist economy will not equal a solar economy qua general economy. From Bataille's claim that the passage from a restricted to a general economy must accomplish a Copernican transformation with "a reversal of thinking - and of ethics" (1991: 25), Szeman makes a step to the idea that "This Copernican change of perspective ne- 
cessitates a politics of revolution rather than reform" (Szeman 2020: 137). What Bataille seem to miss in The Accursed Share is a kind of political strategy: for this, an injection of Marxism is needed. An accomplishment of political revolution toward the solar can only be global and international and start from abandoning the idea of economic growth as the main principle of our societies.

On a global scale, as Bataille says, there is no growth, "but only a luxurious squandering of energy in every form" (1991: 33). Human economies attempt to appropriate its flows and subordinate them to particular finite ends, but, after all, "beyond our immediate ends, man's activity in fact pursues the useless and infinite fulfillment of the universe" (Ibid: 21). There is always a limit of growth, and an excess that must be spent this or that way. This excess is called "the accursed share." If every surplus is invested in further growth of the system like capital, a catastrophic outcome is just a matter of time. Warfare is an example of such an outcome; particularly the prospect of the nuclear war was a matter of concern for Bataille and people of his generation. Bataille's general economy is paradoxically rational: what it suggests is recognizing the limits of growth and thinking through the strategies of nonproductive expenditure as self-conscious activity. We should stop being greedy and stop striving for individual growth, which ends up with planetary energy restoring its balance in an uncontrolled and catastrophic way. Nonproductive expenditure must be taken seriously and organized as a conscious politics of gifts without reciprocation - a glorious politics. As emphasized by Allan Stoekl in his very important book Bataille's Peak: Energy, Religion, and Postsustainability (2007), which explores Bataille's general economy as the theory for the twenty-first century, this approach promotes a new ecological ethics:

Bataille's theory is profoundly ethical but only in the sense that the instant of preservation, of meaning, of conservation, of knowledge, is the unforeseen offshoot of another movement, that of the drive to spend without counting, without attempting to anticipate return. [...] Not nuclear war, but the channeling of excess [...] not generalized ecocide, but an affirmation of another energy, another religion, another waste, entailing not so much a steady state sustainability (with what stable referent? Man?) but instead a postsustainable state in which we labor in order to expend, not conserve. (Stoekl 2007: 32-59)

In order to make this point clearer, I would like to mention the two biggest challenges of today. Starting to spread in January 2020, 
COVID-19 impetuously develops into a proper global pandemic that causes thousands of deaths worldwide and results in a serious crisis to which national governments propose different responses, such as home-office regimes of work and quarantines at schools, universities, enterprises; suspending flights; cancelling sport, business, cultural, and academic events; evacuation of foreigners; closing state borders; mobilization of armies, declaring states of emergency or even exception. The deadly infection revealed the fact that humanity is vulnerable and that neither the global capitalist system nor nation-states can guarantee the security of the people, in spite of all restrictions introduced at local levels that go as far as violating basic human rights and freedoms such as the freedom of movement. What moves freely in spite of all restrictions is the virus; it does not respect borders, and, through the viral proximity of death, demonstrates how everything is connected on multiple levels - people and other animals, weather conditions, surfaces of things, interfaces and infrastructures, currency rates, science, emotions, air pollution, cultural developments and industry machines. The logic of this connection differs from the one that could be described in terms of the rules of the market, and some private adventures to make a profit out of this situation-like the resale of protective masks or hand sanitizer-look repulsive and weird.

In the face of the pandemic with its catastrophic effects, restricted neoliberal economies show how narrow are the limits of their possibilities. As noted by Michael Marder, it is not a mere coincidence that the virus received the name "corona": "Transgressing old borders, the virus becomes a figure of sovereignty in the age of the dispersion of power" (Marder 2000). States' reaction to the pandemic is analogous to the one on migration: they create barriers, but the virus goes through. If we were to think of responses on a planetary scale, we would have to discuss the possibilities of "global coordination and collaboration" (Žižek 2020), of using state power "to channel resources from the private sector to socially necessary directions" (Sotiris 2020), and, finally, reshaping the entire system of the world economy according to the principles of solidarity, gratuitousness, sharing, and thinking of the whole. Pandemic invites the glorious spending of the enormous wealth of certain countries and individuals and to transfer their excessive resources to the most affected areas where they are really needed. Instead, restricted local economies tend to isolate particular units: first countries close their borders, then provinces and cities, then families lock inside their apartments, then individuals must develop social distance and defend their bodies with facial masks, glasses, gloves, and sanitizers. 
These restrictive measures are taken in order to slow down the outburst in order to avoid the healthcare system's overload and gain time until a new vaccine is developed. They seem reasonable, indeed, but in a situation of global inequality throwing all countries upon their own resources leads to Darwinian strategies of the survival of the fittest that in some areas - due to the lack of medical infrastructure like beds and ventilators for intensive care-compel doctors to decide whose lives are worth struggling for - as in the case of Italy, where some infected elderly people were left without medical care. Thus, in fact, a restricted economy becomes a human element of planetary destruction: instead of consciously expending wealth to provide healthcare for everyone regardless of their age and nationality, it squanders people. If we look at families and individuals, we see that their first reaction to the outburst, especially in rich countries, was panic buying that created a shortage of basic commodities. On the level of separate households, people behave like restrictive micro-economies, reasoning their compulsion to consume by the necessity to store supplies in order to be on the safe side; however, on the planetary scale, what they are really doing is wasting: consumers throw away money for immoderate amounts of toilet paper, as if they followed some unconscious drive to waste that in fact corresponds to the general economy. Panic buying is the new potlatch.

It is only fair to say, however, that humanity's reaction to the pandemic cannot be reduced to restrictive measures. In fact, there are new social and individual initiatives that introduce perspective elements of general economy, from more traditional gestures of solidarity - financial aid to the most affected countries or groups, sending them medical equipment for free, volunteering, and so on - to providing free access to electronic museums, libraries, and other cultural and educational products. These examples help to clearly differentiate not only between general and restrictive economies, but between planetary waste (echoed, for instance, by the unconscious wasting by capitalist consumers devastating stores) and expenditure as politics or self-conscious activity, as proposed by Bataille in The Accursed Share. Establishing a difference between waste and expenditure is one of the main points of Stoekl's analysis of this book. Contemporary restrictive economies that are at the same time extractive ones, as they are based on the processes of burning fossil fuels - are in fact the economies of waste, that have to be confronted by the general economy: we have to learn to expend non-productively and at the same time consciously (Stoekl 2007).

To take another example, climate change can be regarded as a destructive planetary phenomenon, and various attempts to control it 
in separate countries - for instance, through introducing carbon tax policies - as restrictive economic measures that only increase the overall mess. Accelerating greenhouse gas emissions and pollution affect the atmosphere and the ocean in its entirety, and not only in the areas of the most intense burning of fossil fuels, heavy industry, or deforestation. The air is common, as is water; it freely distributes heat, as well as pollution and viruses, all over the place. Only global coordination, deciding not on how much we can take from nature, but on how much we can give to it without reciprocation, could work as the general economy that would equal general ecology.

\section{From General Economy to General Politics}

If we apply Bataille's theory of general economy to pandemic, climate change, environmental crisis, and other contemporary global challenges, we can interpret them as signs of nature's striving for squander reinforced by anthropogenic factors - industry, agriculture, tourism, extraction of fuels, and so on - that at the end of the day turns fatal for humans. People infected with COVID-19 that cannot receive medical treatment because hospitals are overwhelmed, whales or seabirds that die after eating plastic items, burning forests in Australia and Siberia, reindeer-breeders and their herds exposed to the anthrax outbreak that was caused by the melting of permafrost on Yamal Peninsula (see Plester 2017), disappearing wild bees and other beings suffering from the global processes that humanity has triggered but cannot control - all seem to become offerings on the planetary debauchery irradiated by the sun. Human beings with their restrictive economies are the active part of it. They think that they struggle for survival or work for prosperity, but altogether their economic activities only contribute to the planetary feast indistinguishable from a plague.

It is this destructive aspect of the accursed share, outlined by Bataille, that relates to his later concept of full violence, or violence of the nonhuman, presented in "Pure Happiness." I argue that the two kinds of economy and the two kinds of violence in Bataille correlate in the following way: any form of human violence belongs to the domain of the restricted economy that comprises all sorts of practical activities of human beings within the circle of means and goals, whereas nonhuman violence, or violence of the second kind, refers to the planetary level of the excess of energy, and therefore can be also called "solar violence." In the perspective of contemporary theoretical debates on the clash between humans and nature, let me put it like this: what Bataille meant by restricted economy 
was not only capitalism or Soviet communism that he criticized for its cult of production, but something more comprehensive, pointing to the antagonistic relation between nature and humans that pretend to be separate from it, to manipulate or replace it. In Bataille, this separation is the essential aspect of anthropogenesis: the human being is an animal that rejects its animal nature; all that is natural must be repelled beyond the line of prohibition that marks the border between the sacred and the profane. Sacred is what has been prohibited or excluded; all gods are born on that side-first as animals, plants, the earth and, indeed, the sun. We do not have direct access to this world; the way to it lies only through the ritual transgression of prohibitions. In turn, on this side, humans create their own world that Bataille called profane - the world of utility and labor, which leans to restricted economies.

Today we are led to suggest that the restricted economy also refers to the Anthropocene. A profane violence of the Anthropocene can be compared to the restricted violence of reason that excludes what it cannot convert into its object (the nonhuman) and thus produces an excess that returns as repressed, rebels as oppressed, or, to put it in Bataillean terms, raises as the god of violence: pandemic or climate change are manifestations of the divine violence of the nonhuman, or solar violence. It "offers itself as the only answer" to the violence of the Anthropocene. Contemporary ecological awareness reveals climate change, mass extinction, and other catastrophic phenomena that get out of human control as partly or entirely anthropogenic or technogenic. There is a tempting image of the human race abusing nature that either passively dies, falling victim to this abuse, or tries to take revenge, for instance, with the grasshopper plague or the appearance of new, stronger viruses like COVID-19. Going back to the aforementioned examples: on the one hand, the pandemic itself was reportedly caused by the complex anthropogenic impact on the environment with wild animal trade as its key element; on the other, the coronavirus outbreak drastically decreased carbon emissions and air pollution due to the reduction of energy and transport use, as if the planet was really trying to take revenge over its troublesome part called humanity, or even used the virus as an instrument to restore its atmospheric balance. As Slavoj Žižek puts it, "when nature is attacking us with viruses, it is in a way sending our own message back to us. The message is: what you did to me, I am now doing to you" (2020).

Nonhuman violence can indeed be understood as a response to human violence, and the turbulence of the Earth interpreted as responsive violent acts analogous to proletarian strikes, revolutionary 
movements, and decolonizing struggles, as if nature could manifest its unwillingness to be exploited or colonized, and its capacity to fight back: thus nature acquires serious political vigor. However, if we hold on to the Bataillean perspective, we would have to acknowledge that addressing nature in terms of justice, rage, or vindication, as well as in terms of means and ends, transfers solar violence into the language of restricted economy. We can use this translation, keeping in mind that something essential might get lost in it and the original "message" seriously differs from that which we receive. In nature, there is no "me" and "you." The earth does not really strike back, does not act responsively and all the more intentionally. It stays indifferent to human affairs. The divine violence of the nonhuman is asymmetrical to the restrictive violence of reason, capital, or Anthropocene; the whole does not behave as an individual.

The indifference of nature and the incommensurability of the two languages, two economies, and two kinds of violence - to put it bluntly, human and planetary-does not mean, however, that general politics, relevant to the general economy, is not possible. As was already emphasized, according to Bataille humanity can and must think of the economic models that overcome the restrictedness of existing forms of exchange and production, that always end up with destruction, be it warfare, as Bataille suggested, or climate change in my interpretation. General economy takes the luxurious character of nature as its starting point and develops it into quite an elevated form of self-consciousness that transforms the destruction, or waste into nonproductive expenditure, of the gift economy. Behaving restrictedly, that is, competing, striving for profit, accumulation and growth, is not self-conscious. It is a mere survival strategy of individual organisms, be they humans or other animals, but also entire nation-states that, particularly in the face of crisis, act as egotistic individuals. Becoming self-conscious means, economy-wise, learning to share.

The idea of the necessity of sharing that takes nonhuman nature as its model is adopted by contemporary philosophers such as Luce Irigaray, who claims that the future will be one of sharing, if there will be one at all: "Starting from the sharing of organic and inorganic nature, it would be possible to elaborate a way of thinking and living that is ecological, instead of economic - in other words, non-possessive, non-appropriative, but participatory with regard to a greater whole...” (2015). In Irigaray's view, learning to share is an urgency in our economies because "the prospects for life on earth depend on it" (Ibid). It is true, of course, and it seems that, understood as such, the ecology that must replace economy echoes 
Bataille's general economy that must replace a restricted one. Yes, general economy could stay for today's ecology, but there is one nuance: the urgency of today's ecology - to save life on earth - seem to send it back to the all-too-human register of means and goals. Bataille's sun shines aimlessly. All life on earth is just an effect of its sovereign violence. We must learn to share not because we want to live, but because sharing is glorious. It breaks with utility, with the logic of survival. In the Bataillean perspective, understanding the earth, or nature, or the nonhuman in a broad sense, as an economic agency that, like humans, pursues its interests, would be wrong. The point is not to translate from the general to the restricted, but from the restricted to the general: if we want to commensurate our economies with our environments, we have to become solar, and not the other way around.

Bataille's notion of violence - and the difference between the two kinds of violence - allows for the creation of a bridge from general economy to general politics that is only sketched here but deserves to be developed at a greater length in some future work. Basically, the idea is the following: for a general emancipatory politics, the point is not to interpret solar violence - pandemic outbreak, climate change, volcano eruptions, tornadoes, and so on - as nature's revolt analogous to human emancipatory struggles, but to grasp human emancipatory struggles as solar violence that correlates to the solar economy. Roughly said, nature does not strike, because it does not care, but: what if a human strike could go really general-not in terms of Sorel, but rather in terms of Bataille? Thus, one of the most shocking effects of the coronavirus is that it interrupts, not entirely, of course, but partly at least - due to necessary quarantine measures - the processes of capitalist production and exchange. Some employed become unemployed, others are sent to a kind of involuntary vacation. Offices and institutions are closed, and the work is stopped or reduced, with a serious loss for individuals and countries relying on their restrictive policies, so that the considerable intervention of states is needed in order to preserve the capitalism system, in whose indissolubility the absolute majority of people so strongly believed only yesterday. Does this sudden interruption not refer to some perverted image of the general strike? From the quarantine to the viral strike; from climate change to the solar strike - these could be the mottos for a general politics in times of pandemics and global warming. If we put it like this, we should explain the strike not as an expression of need, but as an excessive wave of dangerous festivities that replace work. Decolonization or revolutionary violence, too, can be interpreted as general, if we extend it from the domain of human 
history to the domain of natural activities, and grasp not, say, climate change as a rebellion of the colonized Earth or revolutionary movement of the oppressed nature, but human decolonizing struggles and revolutionary movements as radical climate change: it is getting hot.

To make things clear: general economy as political project comprises the self-conscious activity of people that takes the solar economy of the universe as its model. In this, it is opposed to the restricted policies that seem to save and preserve as well as to grow and accumulate, but in fact unconsciously follow the planetary drive for destruction, which is seemed to confront. In turn, self-conscious activity will seem to repeat planetary debauchery, but in fact will dialectically transform it into glorious nonproductive expenditures. I do not suggest any new form of politics, but invite the rethinking of existing ones. Every progressive protest movement, every strike, every revolution already carries this sovereign, festive, luxurious moment, but it remains shadowed by the restricted, one-sided logics of usefulness that cannot encompass the totality of the ecological whole.

\section{Instead of a Conclusion: The Missing Link}

Something is missing, however, in this passage from Bataille's general economy to a general politics, and that is why, at the end of the day, it does not look entirely convincing and leaves an impression (a wrong one, indeed) that the only thing we could suggest, together with Bataille, is a kind of feast in times of plague. My hypothesis is that the missing link here is a coherent theory of labor. Among the few things that I find problematic in Bataille, whose idea of the planetary excess of energy is a starting point of my interrogation, is that the sacred wastefulness of nature is opposed to labor as the restricted, or profane human economy. In Bataille's universe, labor means subordination. Only humans and some other animals, enslaved by humans, work; what the sun does is a luxurious idleness and in no way labor.

I would like to emphasize, however, that labor is never subsumed entirely. According to Carolyne Merchant (2016) nature is autonomous, and the same can be said for labor. In his book The Progress of this Storm: Nature and Society in a Warming World (2018), Andreas Malm emphasizes that both nature and labor are essentially autonomous from capital:

Both are ontologically prior to it, antedate its appearance on earth, have a history as long as human history in the former case and geo- 
logical history in the latter of operating according to their own laws, and however hard various ruling classes have subsequently sought to control them [...] that autonomy persists below the surface, even when the volcanoes are dormant. (Malm 2018: 197)

My hypothesis is that general economy as a possible theory for the twenty-first century would benefit from overcoming Bataille's negative construct of labor toward a dialectical unity with its opposite, that is idleness and leisure. Bataille pins labor to the restricted economy, but there is a way to detach them. For this, we have to supplement the general economy proposed by Bataille - and the general politics briefly outlined here-with some elements of Marxist analysis of labor, that at first thought sounds alien to it. If we connect Bataille's restrictive economies to the Marxian theory of the exploitation of estranged labor that produces value crucial for the growth of capital, then general economy seems to be open to engage with the idea of non-alienated work, essentially free and indiscernible from luxurious leisure. Marx already envisioned such a perspective. Thus, Artemy Magun points to the "antithetic" character of leisure activity in Marx:

It constitutes the only free, authentic human action - but at the same time the cunning exploitation of it by capitalism (paying for your free labor) makes possible the cyclic, infinite, and frenetic increase of capitalist production. The more technical progress succeeds in reducing necessary labor, that is, in liberating time - the more vigorously does capitalist economy "convert" this free time into "surplus labor." Such exploitation of this overabundant, surplus force would, according to Marx, lead capitalism into the crisis of overproduction and allow working masses to "reappropriate" their surplus labor for their free development. (Magun 2003: 1153)

As noted by Magun (2010: 97), Bataille further develops these ideas by turning it from productive labor to nonproductive expenditure, but does not really articulate how his own ideas correspond to Marx's theory. A connection between Bataille's squander and Marx's leisure can be traced through the concept of free play (freies Spiele) referred to by Marx (Ibid; Marx and Engels 1975-2005: 35.270). A good term was recently suggested by Marder, who, in his book Energy Dreams: On Actuality analyzes the "generally unproductive activity both in Marx and Bataille": instead of employment, he speaks of "emplayment": "putting into play what, in some instances, will turn out to be work" (Marder 2017: 74). An example of such an activity is a singer who 
sings like a bird, just because she wants to do so. It is work, but it does not produce value and is not taken over by capital. According to Marx, this capacity to work freely (what is this if not some excess of energy?) is essential and constitutive for all human beings. Originally, work is not subordination, but freedom. My idea is that this freedom equals our inborn solarity, but it is being exchanged for money on the market as a mere commodity, or labor force.

This theory, in turn, can also be developed and enforced with some elements of general economy, for which labor has to be de-anthropologized: on the planetary scale, everything and everybody is either emplayed or employed. Not only humans, but other animals, as well as the sun, and the earth with its depths, do work and are exploited by humans, and thus are getting absorbed into restrictive economies, for which they keep answering with their full violence. What connects nature and labor is energy. Restricted capitalist economies exploit initially free human and nonhuman energy as an alienated workforce or natural resource, and incessantly transform the sun's glorious work of shining into commodified fossil fuels. The passage from a general economy to a general politics will remain incomplete if we do not overcome Bataille's opposition between the planetary and the human, as between nature and labor, through its intertwining with the Marxist conception of work extended to the level of the biosphere.

\section{References}

Bataille, Georges (1985). Visions of Excess: Selected Writings 1927-1939. Minneapolis: University of Minnesota Press.

Bataille, Georges (1989). Theory of Religion. New York: Zone Books.

Bataille, Georges (1991). The Accursed Share: An Essay on General Economy, Vol. I. Consumption. New York: Zone Books.

Bataille, Georges (2001). The Unfinished System of Non-Knowledge. Minneapolis: University of Minnesota Press.

Bellamy, Brent, and Jeff Diamanti, eds. (2018). Materialism and the Critique of Energy. Chicago: MCM Press.

Benjamin, Walter (1996). Selected Writings. Vol. 1. 1913-1926. Cambridge, MA: Harvard University Press.

Boetzkes, Amanda (2017). “Solar.” In: Fueling Culture: 101 Words for Energy and Environment, eds. Imre Szeman, Jennifer Wenzel, and Patricia Yaeger, 48-251. New York: Fordham University Press.

Fanon, Frantz (1963). All the Wretched of the Earth. New York: Grove Press.

Freud, Sigmund (1964). The Standard Edition of the Complete Psychological Works of Sigmund Freud, Volume XIV (1914-1916): On the History of the Psycho-Analytic Movement, Papers on Metapsychology and Other Works. London: Hogarth.

Irigaray, Luce (2015). “Towards an Ecology Of Sharing.” The Philosophical Salon. https://thephilosophicalsalon.com/toward-an-ecology-of-sharing

Kendall, Stuart (2007). Georges Bataille. London: Reaktion. 
Khatib, Sami (2011). “Towards a Politics of 'Pure Means': Walter Benjamin and the Question of Violence.” Anthropological Materialism. https://anthropologicalmaterialism.hypotheses.org/1040.

Magun, Artemy (2003). "The Work of Leisure: The Figure of Empty Time in the Poetics of Holderlin and Mandelstam.” MLN 118.5: 1152-76.

Magun, Artemy (2010). "Marx's Theory of Time and the Present Historical Moment." Rethinking Marxism 22:1: 90-109.

Malm, Andreas (2018). The Progress of This Storm: Nature and Society in a Warming World. London: Verso.

Marder, Michael (2017). Energy Dreams: On Actuality. New York: Columbia University Press.

Marder, Michael (2020). “The Coronavirus is Us.” New York Times. https://www. nytimes.com/2020/03/03/opinion/the-coronavirus-is-us.html

Marx, Karl (1959). "Economic and Philosophic Manuscripts of 1844." Moscow: Progress Publishing.

Marx, Karl, and Friedrich Engels (1975-2005). Collected Works. Moscow: Progress Publishers/

Merchant, Carolyne (2016). Autonomous Nature: Problems of Prediction and Control from Ancient Times to the Scientific Revolution. New York: Routledge.

Noys, Benjamin (2000). Bataille: A Critical Introduction. London: Pluto Press.

Plester, Jeremy (2017). "All the Hell Breaks Loose as the Tundra Thaws." Guardian, July 20, 2017. https://www.theguardian.com/environment/2017/jul/20/hellbreaks-loose-tundra-thaws-weatherwatch

Sorel, Georges (2004). Reflections on Violence. Cambridge: Cambridge University Press.

Sotiris, Panagiotis (2020). "Against Agamben, is a Democratic Biopolitics Possible?” Lasting Future. https://lastingfuture.blogspot.com/2020/03/against-agamben-is-democratic.html?fbclid=IwAR2ofuB22YLjcNOAkuZxx7SSAnZwYzLy5KPExHJJ-MYcptgcY9MhuQ2mntM.

Szeman, Imre (2020). “On Solarity: Six Principles for Energy and Society After Oil” Stasis. 2020: 128-143.

Szeman, Imre, and Dominic Boyer, eds. (2017). Energy Humanities: An Anthology. Baltimore: Johns Hopkins University Press.

Stoekl, Allan (2007). Bataille's Peak: Energy, Religion, and Postsustainability. Minneapolis: University of Minnesota Press.

Yusoff, Kathryn (2015). “Geologic subjects: nonhuman origins, geomorphic aesthetics and the art of becoming inhuman.” Cultural Geographies 22.3: 383-407.

Žižek, Slavoj (2008). Violence: Six Sideways Reflections. New York: Picador.

Žižek, Slavoj (2020). “Monitor and Punish: Yes, Please!” The Philosophical Salon. https://thephilosophicalsalon.com/monitor-and-punish-yes-please/?fbclid=IwAR2y0bICobOIuFe5kqWcqtVwu03fysjwkC6sqJcPEbL8RtbjKGlYC2r0if8. 